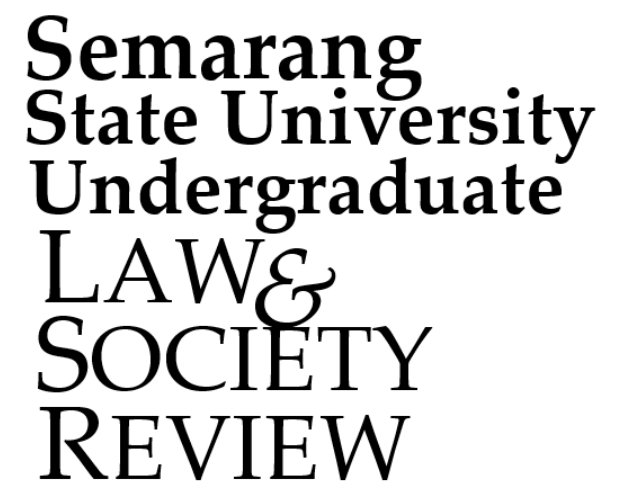

VOLUME 1 ISSUE 1, JANUARY 2021
ISSN (Print): 2807-8225 ISSN (Online): 2807-8683

\author{
History of Article \\ Submitted: November 2020 \\ Revised: December 2020 \\ Accepted: January 2021 \\ How to cite:
}

Ramadhani, D. K., Ifandi, M. F., \& Az Shaidah, Z. (2021). Movie Review Harmony (2010), Director: Kang Dae Kyu, Script Writers: Lee Seung Yeon, Yoon Je Kyun, Kim Whee, and Kang Dae Kyu, Production: CJ Entertainment Korea. Semarang State University Undergraduate Law and Society Review, 1(1). https://doi.org/10.15294/lsr.v1i1.50618

(C) 2021 Authors. This work is licensed under a AttributionNonCommercial-ShareAlike 4.0 International (CC BY-NC-SA 4.0). All writings published in this journal are personal views of the authors and do not represent the views of this journal and the author's affiliated institutions.

\title{
Movie Review Harmony (2010), Director: Kang Dae Kyu, Script Writers: Lee Seung Yeon, Yoon Je Kyun, Kim Whee, and Kang Dae Kyu, Production: CJ Entertainment Korea
}

Defarah Kamila RAMADHANI@ Muhammad Fajar IFANDI® Zahra Az SHAIDAH®

Universitas Negeri Semarang J1. Kampus Timur, Sekaran, Gunungpati, Semarang, INDONESIA 凶defarah.kamila@gmail.com

\begin{abstract}
This film tells the story of life in a women's prison. It shows how much trauma and remorse are in the prisoners. The main character is Jeong Hye, she is imprisoned for killing her violent husband. Jeong Hye also lives with several other inmates in one cell.
\end{abstract}

KEYWORDS. Movie Review, Harmony, Korean Movie, Prisoner 


\section{GENERAL SYNOPSIS}

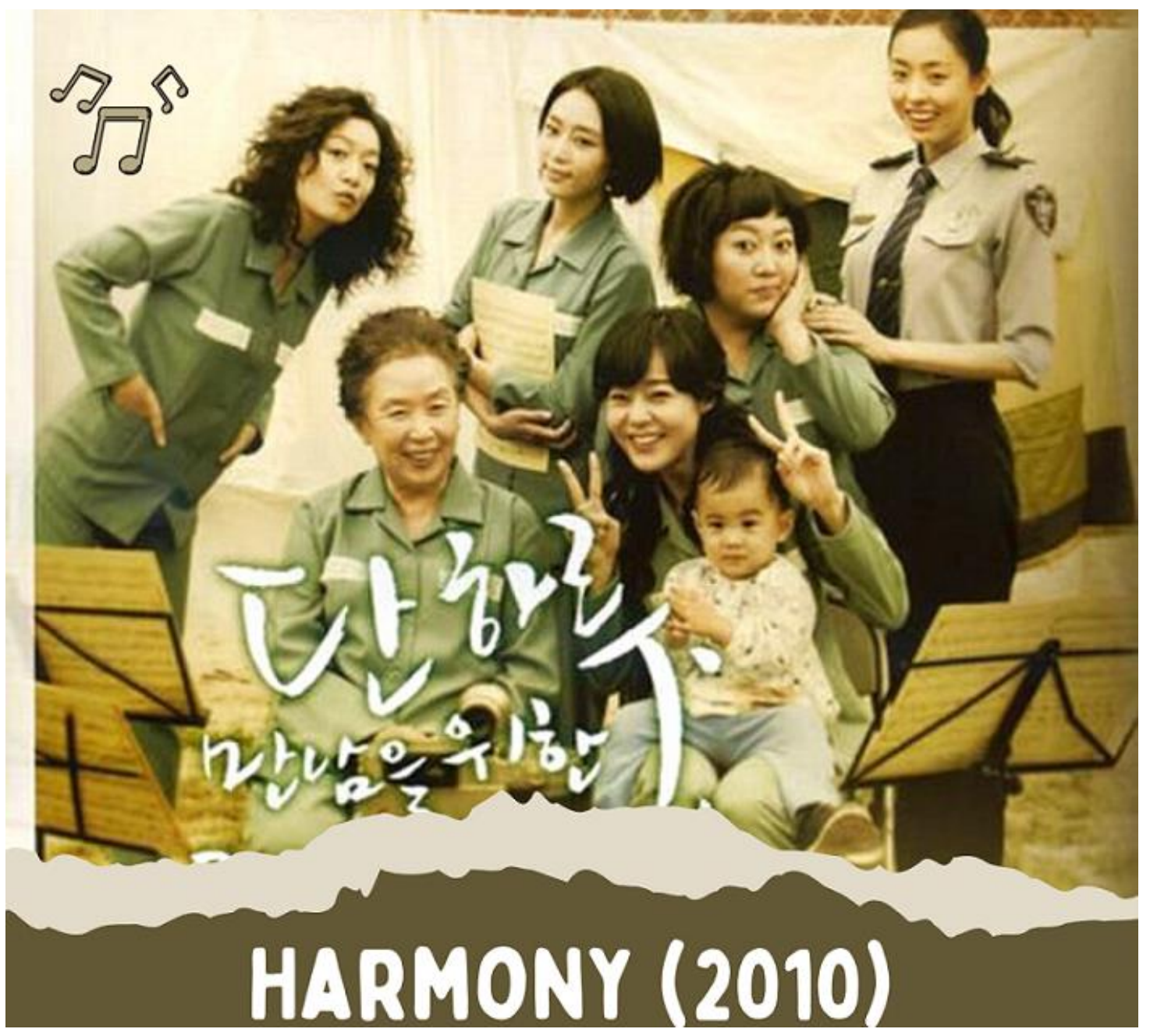

This film tells the story of life in a women's prison. It shows how much trauma and remorse are in the prisoners. The main character is Jeong Hye, she is imprisoned for killing her violent husband. Jeong Hye also lives with several other inmates in one cell. The first one is Moon-ok who was to kill her husband because he cheated on her. The second one is Yomi who was forced to kill her stepfather because he sexually abused her, and her mom didn't defend her. Also, there were two other prisoners in that cell with other cases. 
Jeong Hye gave birth to a child in prison named Min-Woo. Min-Woo never gets out of jail since he was born. Jeong Hye wants a day out with her child. One day they were Choir Team perform in the prison, which gave Jeong Hye an idea. She has the idea to make a choir team and if it works the officer will be given Jeong Hye a day to go out with her son.

The process of making a choir team is not that easy, Jeong Hye had trouble finding the leader for the choir team, because she is not capable enough to do that. Moon-ok was a music teacher, at first, she didn't want to be the leader, but in the end, she did that because she wants to help Jeong Hye and Min Woo. After that, there was a new problem, there are not enough good singers to make a choir team. But it turns out Yomi has a really good voice, at first, she didn't want to join but Moon-ok persuade her.

Even though there were many obstacles, it did not prevent the choir team to performing their best. Because the performance of the choir team is really good, the officer gave her a day out with her child. But the day turned out to be the last day Jeong Hye met her child because her child need to be handed over to an orphanage. The movie shows how sad it is for a mother who has to let her child go.

After that, the choir team did not stop practicing until they were invited to perform on Christmas Eve. The officer allowed them to invite family to watch. Told some prisoners were very happy because they had the opportunity to meet their families. But some prisoners are sad because they remember their families who don't want to see them.

After they performed, they got a chance to meet the family. Likewise, with Jeong Hye, she met her son. Also featured are several other inmates who are finally able to meet their loved ones. Yomi finally be able to forgiver her mother. Moon-ok finally be able to meet her son, but her daughter still didn't want to see her.

After Christmas eve, suddenly Moon-ok has a chance to go home and met her son and daughter. On that day, her daughter finally be able to forgive Moon-ok. They eat and sleep together like a happy family. But 
actually, that will be the last chance Moon-ok met her family because she will be executed later.

On the day Moon-ok will be executed, the officer is calling her to go out from the cell, all the prisoners were very sad. There were crying and singing while letting Moon-ok go.

All the things that the prisoners did, is nothing without the help of Officer Kong. Officer Kong is very kind. She always helping all of the prisoners. She helps Jeong Hye to make a choir team, she also helps Jeong Hye to celebrate Min Woo's first birthday. Even she takes a part in the choir team as a pianist.

The movie was really sad, it really shows how hard living in a woman's prison is, how hard living as prisoners, and how hard forgiving themself for what they already did. Also how hard getting hated by their loved ones.

\section{LEGAL ISSUES ON THE MOVIE}

A wife commits the crime of murder, which is to kill her own husband. This case began when the husband accused his wife of having an affair and adultery with another man. Her husband accused her without evidence. Then there was bickering and domestic violence, and the husband accidentally fell and died. Supposedly, the husband should not just accuse his wife of having an affair and adultery without any evidence, don't just suspect it.

In accordance with article 33 Chapter VI concerning the rights and obligations of husband and wife, husband and wife are obliged to love each other and respect each other; so husband and wife must respect each other and should not just accuse.

And according to Article 44 paragraph (1): "Anyone who commits acts of physical violence within the scope of the household as referred to in Article 5 letter a, with this article we already know that the actions taken by the husband against his wife violate the law. In the end the husband 
died because his wife killed him accidentally (during a fight the husband was pushed by his wife until he fell).

For this incident the wife was charged with the law on involuntary manslaughter, even though the wife killed her husband accidentally and would certainly go to jail. The prosecutor should reconsider the sentence he received, given the events that took place when the murder took place.

\section{WHAT WE LEARN AS LAW STUDENT FROM THE MOVIE?}

The film tells the story of the lives of female inmates who are found guilty of violating criminal law. At the beginning of the film, it starts with a flashback of how these female inmates can get inside the prison. A grandmother named Kim Moon-Ok is one of the inmates who committed a murder case against her husband and her husband's affair. By bringing a car then hit her husband and his affair who was then out of the apartment. The grandmother was sentenced to death by the court. In addition, other inmates also have the same case, namely murder. It's all caused by the revenge, sadness, and indignity felt by the inmates in the film.

So, in the "Harmony", we can learn that every action we take has to think about how risky it is. In addition, every action must have a cause of effect. Actually, the action taken is self-defence, but in law if it reaches murder then it remains guilty as contained in the rules. 


\section{Conflicting Interest Statement}

All authors declared that there is no potential conflict of interest on publishing this article.

\section{Funding}

None

\section{Publishing Ethical and Originality Statement}

All authors declared that this work is original and has never been published in any form and in any media, nor is it under consideration for publication in any journal, and all sources cited in this work refer to the basic standards of scientific citation. 